\title{
Empirical analysis of FDI and Economic growth in Gansu China: based on time-series data from 1986 to 2010
}

\author{
Jing Shi * \\ School of Economics and Management, Lanzhou University of Arts and Science, \\ Lanzhou (730030), P.R.China, \\ shijing826415@126.com
}

Keywords: FDI; Economic growth; Empirical analysis; Gansu.

\begin{abstract}
In this paper, we analyze causal relationship between foreign direct investment (FDI) and economic growth of Gansu province in China using time-series data from 1986-2010. The analysis is conducted by the means of time-series estimations through ADF unit root test, co-integration tests, error-correction analysis and Granger causality test. The purpose of the paper is to empirically investigate the impact of economic growth on FDI of Gansu in China. The results suggest that FDI does not appear to Granger-cause economic growth, and economic growth also does not significantly affect FDI, which means some studies have overestimated the positive effect of FDI on economic growth, and underestimated the influence of economic growth on FDI.
\end{abstract}

\section{Introduction}

FDI (Foreign Direct Investment) has contributed significantly to the economic development since reform and opening up in China. However the geographic distribution of the FDI is quite uneven, the relation between FDI and economic growth become the hot issues for decades. There have been vast numbers of empirical research to examine the impact of FDI on the economic growth of host countries. However, there is still no consensus on the relationship between FDI and economic growth. Some suggested that FDI are positively related to economic growth [1-3], while others investigated that they are not the truth [4-5]. Some empirical studies show that both FDI and economic growth are interdependent and could lead to two way causality [6]. From the above overview, we can find a blurred picture that the relationship between FDI and economic growth is not clear, and one specific growth-enhancing effect of FDI is ambiguous in their findings. Blonigen and Wang [7] illustrate the importance of distinguishing between developed and developing countries. Other scholars have successfully addressed the endogeneity problem between FDI and economic growth by means of instrumental variables techniques [3,8], Granger causality or VAR/VECM frameworks [9] or the Arrelano-Bond generalized method of moments (GMM) approach [10]. In china, an increasing number of studies also attempted to reveal the regional distribution of FDI and economic growth. Wei [11] studied the great disparity between coastal and inland regions of FDI and economic growth. Li [12] examined the uneven distribution among three regions. These studies confirmed the uneven distribution of FDI and its positive power in China economy. Since "go west" policy, the growing FDI into western region has become an important driving force of economic development. As the poorly-functioned province, Gansu is located in remote and inland of China with poor economic situation, there are few studies providing the causal relationships between FDI and economic growth, especially in less-developed western region with large number of minorities' population. The objective in this paper is to examine the causal relationships between FDI and economic growth of Gansu in China and to find its dynamical mechanism. The rest of this paper is organized as follows: section 2 presents data and methodology used in the paper. Section 3 examines empirical analysis and findings of causal relationships between FDI and economic growth. The last section is the conclusion and implications. 


\section{Date and Methodology}

In this paper, FDI is measured as the amount of foreign capital actually utilized and economic growth is measured as real GDP. The relationship between $G D P$ and $F D I$ of Gansu is examined on the basis of annual time series data for the period of 1986-2010. All the data used in this paper are obtained from China Statistics Yearbook 1987-2011. To achieve consistency, data reported in RMB are converted into USD dollars based on the current year average market exchange rates, which are produced by National Bureau of Statistics in China. For testing purpose, all time -series are expressed in real terms using a $G D P$ deflator $(1978=100)$ and in natural logarithms.

In order to avoid spurious regression situation, all variables in a regression model must be stationary or co-integrated. However, several empirical studies concluded that many macroeconomic time series data are non-stationary. Therefore, in the first step, unit root tests are performed on the time series to investigate stationary on both $G D P$ and FDI. According to Engle and Granger [13], if two variables are integrated of order one, 1 (1), and are co-integrated, then either uni-directional or bi-directional Granger causality must exist in the 1(0) variables once the two series satisfy the unit root properties, the paper carries out the co-integration test to examine whether there is a cause-and-effect relationship between $G D P$ and $F D I$ of Gansu in China. If the two series variables are found to be co-integrated, then we retrieve the error correction term from the co-integrating equation and test the direction of causation. If the two variables are not co-integrated, then we employ Granger's causality to test the direction of short-run causation.

\section{Empirical analysis and findings}

Unit Root Test. The augmented Dickey-Fuller test (ADF) (Dickey \& Fuller, 1979) [14] is a test for a unit root in a time series sample. It's the augmented version of the Dickey-Fuller (DF) test for resolving the existence of autocorrelations phenomenon. It's also a larger and more complicated set of time series models, and it indicates the error term is not white noise. In order to check non-stationary in level form, we investigate the stationarity of the first difference of the series by testing for unit roots. It could be divided into three main versions which stating as followings:

No constant and no trend model:

$$
\Delta y_{t}=w y_{t-1}+\sum_{i=1}^{k} \beta_{i} \Delta y_{t-i}+\varepsilon_{t}
$$

Constant and no trend model:

$$
\Delta y_{t}=\alpha_{0}+\omega y_{t-1}+\sum_{i=1}^{k} \beta_{i} \Delta y_{t-i+1}+\varepsilon_{t}
$$

Constant and trend model:

$$
\Delta y_{t}=\alpha_{0}+\alpha_{1} t+\omega y_{t-1}+\sum_{i=1}^{w} \beta_{i} \Delta y_{t-i+1}+\varepsilon_{t}
$$

Where $\Delta$ means first difference, ${ }^{y_{t}}$ is predictor variable, $\alpha$ is the intercept. $\omega$ stands for auto-regression term, $\alpha_{1} t$ is the time trend term and $\sum_{i=1}^{w} \beta_{i} \Delta y_{t-i+1}$ refers to lag term of dependent variables, ${ }^{\varepsilon_{t}}$ represents the error term.

The hypothesis of unit root is: $\mathrm{H} 0: \mathrm{w}=0$ and $\mathrm{H} 1: \mathrm{w} \neq 0$

If the null hypothesis ( $\mathrm{H} 0)$ is rejected, it concludes to reject the variables existing the unit root. Thus, the predictor variable will be the stationary time series.

Table 1 is the results of the ADF test, and it show that the null hypothesis of a unit root is (a) accepted for the level series of GDP in three models; (b) rejected for the level series of FDI in the model (2), and (c) rejected for all the first differenced series (except GDP in model 1). Therefore the null hypothesis of non-stationary could not be rejected, and both of the series are stationary. We can say that both times series are integrated of order $1,1(1)$. 
Table 1 results of ADF unit root test

\begin{tabular}{llll}
\hline Variables & $\begin{array}{l}\text { Model (1) } \\
\text { No constant \& No trend }\end{array}$ & $\begin{array}{c}\text { Model (2) } \\
\text { Constant \& No trend }\end{array}$ & $\begin{array}{c}\text { Model (3) } \\
\text { Constant \& No trend }\end{array}$ \\
\hline 1. ADF test for unit root on the level series & & 0.4512 \\
\hline$G D P$ & 4.3645 & 4.2567 & -2.8422 \\
\hline$F D I$ & 0.7965 & $-3.7441 *$ & \\
\hline 2. ADF test for unit root on the first difference series & & $-6.4512 *$ \\
\hline$G D P$ & 0.9357 & $-4.2776 *$ & $-6.3459 *$ \\
\hline$F D I$ & $-5.537 *$ & $-6.3789 *$ & \\
\hline
\end{tabular}

Notes: * denotes significance at the $1 \%$ level

Co-integration test. Since all the data series are integrated processes of order 1 (1), the co-integration test will be performed to examine the long run or equilibrium relationship between the variables of $G D P$ and $F D I$. The co-integration test applies the best method of co-integration $\log$ likehood ratio (LR) brought forward by Johanson. The results of the Johanson co-integration is summarised in Table 2, which provide evidence to reject the null of zero co-integrating vectors in favour of one co integrating vector at the $1 \%$ level of significance. The test statistics suggests that there exists a long equilibrium relationship between $G D P$ and $F D I$ of Gansu.

Table 2 Results of Johansen Co-integration Test

\begin{tabular}{c|c|c|c|c|c}
\hline H0:rank=i & Eigenvalue & Likehood & $5 \%$ Critical & $1 \%$ Critical & No. of CE(s) \\
Rank=0 & 0.4712 & 24.165 & 14,65 & Value & 19.64 \\
Rank $\leq 1$ & 0.0573 & 1.3495 & 3.68 & 6.83 & None * \\
\hline
\end{tabular}

Notes: * denotes rejection of the null hypothesis at the $1 \%$ level.

The Error Correction Model. Engle and Granger show that if non-stationary variables are co-integrated, then a vector autoregression (VAR) in the first differences is misspecified. Since a co-integration relationship is found between $G D P$ and $F D I$, an error correction model (ECM) is used to test for intermporal causality between these variables. Table 3 presents the results of the error correction models.

Table 3 The results of the Estimation of Error Correction Model

\begin{tabular}{ccc}
\hline Variables & $\Delta G D P_{t}$ & $\Delta F D I_{t}$ \\
\hline$\Delta G D P_{t-1}$ & $/$ & $\begin{array}{c}0.6959 * \\
(2.6987)\end{array}$ \\
\hline$\Delta F D I_{t-1}$ & -0.0089 & $/$ \\
\hline VECM $_{\mathrm{t}-1}$ & $(-0.1336)$ & $-0.1520 *$ \\
\end{tabular}

Notes: figures in parentheses are t statistics; * denotes significance at the $1 \%$ level

As shown in the table 3, the estimation coefficient of the interpretive variable ${ }_{\Delta} F D I_{t-1}$ in the ${ }_{\triangle} G D P$ equation indicates that $F D I$ reduces $G D P$, however, the ${ }^{p}$ value of null hypothesis of the Wald test statistics is -0.1336 , which shows that the estimation value is beyond statistical significance. The next step of the test is to find out whether the error correction coefficient or co-integration coefficient is zero. Though the error correction coefficient of the $\Delta G D P$ equation is -0.0102 , the ${ }^{p}$ value of the null hypothesis of the Wald test statistic is -0.7368 , which indicates that the significance in statistic terms is null. As a result, the assumption that $F D I$ impels $G D P$ is false.

The same method is applicable to testing whether the economic development of western region attract $F D I$. First of all, the estimation coefficient of $\Delta F D I$ affected by $\Delta F D I_{t-1}$ tells that the economic development of western region stimulates $F D I$, the ${ }^{p}$ value of the null hypothesis of Wald test statistics is 2.7223 , indicating that the assumption in statistics terms is significant. The ${ }^{p}$ value of the null hypothesis with further application of the Wald test is -2.8425 and the significance in statistics terms in not null. The test results support the hypothesis that the economic development attracts $F D I$. 
The Granger Causality Test. If the variables are non-stationary and co integrated, the adequate method to examine the causal relations is the Vector Error Correction Model (VECM) [14]; otherwise a VAR model is used in the case of no co integration found among the variables.

The results of the GC test are shown in Table 4. They indicate that a zero hypothesis that economic development growth does not influence $F D I$ can be rejected which implies adoption of the opposite hypothesis, i.e., that economic growth affects $F D I$. Similarly, a non-rejection of the zero hypotheses that FDI does not influence economic growth implies that we cannot adopt the opposite hypothesis that $F D I$ affects economic growth. In short, the assumption that economic growth attracts $F D I$ is confirmed, reverse causality, i.e. that FDI affects economic growth, is rejected.

Table 4 Granger Causality Test

\begin{tabular}{cccc}
\hline Null hypothesis & Observations & F-Statistics & Probability \\
\hline FDI does not cause GDP & 23 & & 0.3421 \\
\hline GDP does not cause FDI & & 1.43844 & $0.0352 *$ \\
\hline
\end{tabular}

Notes: * denotes significance at the 5\% level

Findings. Since economic growth in western region affects $F D I$ in the light of above analysis, we can establish the following:

$L N F D I=\alpha+\beta L N G D P$

Above Equation is estimated by pooled ordinary least square (Pooled OLS), and the results are shown by E-view6.0 as following:

$L N F D I=1.649+0.571 L N G D P \quad R^{2}=0.936 \quad F=305.995 \quad D W=1.021$

It indicates that economic growth has played a positive role on $F D I$, that is, GDP increase $1 \%, F D I$ will increase $0.57 \%$.

\section{Conclusions}

This paper has analyzed the linkage between $G D P$ and $F D I$ of Gansu province in China, by conducting time-series data through ADF unit root tests, co-integration tests, error-correction analysis and Granger causality test. The results show that FDI does not appear to Granger-cause economic growth and economic growth also does not significantly affect $F D I$. Based on the finding in this paper, we may draw some conclusions related to policy implications for western region China. The result suggests that host government should not only encourage FDI inflows, but also should take measures to improve the quality of utilizing FDI, so as to achieve the goal of promoting economic growth as far as possible. In addition, the result indicates that an equal competing environment should be provided for FDI and domestic investment, to enhance the effect of investment on economic growth.

\section{Acknowledgements}

This work is supported by National Natural Science Foundation (NNSF) of China under grants $61263002 \& 61374054$.

\section{References}

[1] Caves, R, Multinational firms, competition and productivity in host country markets. Economica, 41(1974)176-193. 
[2] Globerman, S, Foreign Direct Investment and spillover efficiency benefits in Canadian manufacturing Industries. Canadian Journal of Economics, 12 (1979)42-56.

[3] Li, X., \& Liu, X: Foreign Direct Investment and economic growth: An increasingly endogenous relationship. World Development, 3(2005)393-407.

[4] Grilli, V. and G.M. Milesi-Ferretti: Economic Effects and Structural Determinants of Capital Control. IMF Staff Papers, 42(1995)517-551.

[5] Borensztein, E., DeGregorio, J., \& Lee, J.-W: How does foreign direct investment affect economic growth? Journal of International Economics, 45(1998)115-135.

[6] Zhang, K.H: Does Foreign Direct Investment Promote Economic Growth? Evidences from East Asia and Latin America[j], Comtemporary Economics Policy, 19(2001)175-185.

[7] Blonigen, B. A., \& Wang, M, Does Foreign Direct Investment promote development? 2005, pp. 221-243. Washington, DC: Institute for International Economics.

[8] Chowdury, A., \& Mavrotas, G: FDI and growth: What causes what? World Economy, 2006(29)9-19.

[9] Durham, J. B. J, Absorptive capacity and the effects of foreign direct investment and equity foreign portfolio investment on economic growth. European Economic Review, 2004(48)285-306

[10] Yao, S. J, On economic growth, FDI and exports in China. Applied Economics, 38(2006)339-351.

[11] Wei Hou-kai, The effect of FDI on regional economic development of China, Economic Research, 2002, pp. 19-26.

[12] Li Xiao-jian, Regional distribution change of FDI in China and the problems of promoting its inflow to inland, Economic Geography, 24(2004)304-308.

[13] Dickey, D.A. and Fuller, W.A, Distribution of Estimators for Time Series Regressions with a Unit Roots. Journal of the American Statistical Association, 74(1979)427-431.

[14] Granger, C. W. J, Some Recent Developments in a Concept of Causality, Journal of Econometrics, 39(1988)199-211

[15] Granger, C. W. J, Investigating Causal Relations by Econometric Models and Cross-Spectral Methods, Econometrica, 37(1969)24-36. 